\section{UNIVERSITY \\ OF DEBRECEN}

FACULTY OF

HEALTH

NYÍREGYHÁZA

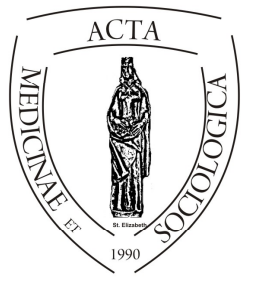

ACTA

MedSoc

VOLUME 5.

2014

\title{
Civil szervezetek, civil engagement, civil érintettség
}

\author{
Szabados György \\ Debreceni Egyetem, Vezetés és Szervezéstudományi Intézet, \\ Vezetéstudományi Tanszék
}

\begin{abstract}
Some literatures mention a civic organization and activity boom in Hungary after the change of the former regime. Although there was an increase in the number of the classic civic organizations, lately this trend has stopped, and we may also expect a decrease in their number owing to the new regulations, requirement of the civic act.

The importance of the sector is usually approached by the figures of the Statistical Office, and we may also exaggerate it regarding economic capacity and human resources, volunteers, but a deep look may reveal a different, diverse picture. It is really hard to estimate the background, effect, movements behind the civic sector, international literatures discuss this issue in the framework of the civic engagement. In a private examination I may also contribute to the better approach of the importance of the civic sector, by studying and measuring the „civic affectedness" complex indicator. This examination revealed a medium or smaller level of affectedness among inhabitants of a dedicated settlement.
\end{abstract}

Keywords: non-profit, NGOs, involvement, Sárrét.

DOI: $10.19055 / \mathrm{ams} .2014 .5 / 14-15 / 5$ 


\section{Bevezető}

Érdekes és fontos lenne tudni, hogy vajon mit is tud ma a társadalom a civil szervezetekről. Amennyiben ma civil szervezetekről beszélünk, az embereknek erről a szervezeti típusról nem mindig ugyanaz jut eszébe. Ha felvetődik a nonprofit elnevezés, valószínúleg az már inkább sokatmondó fogalom, noha a két terminus nem teljesen ugyanaz. Geszti (é.n.: 2) szerint „Már önmagában a civil szervezet megjelölés sem egyértelmü, hiszen minden országban más-más fogalom társul hozzá. Szokás harmadik szektorról is beszélni, megkülönböztetve ezáltal az állami és üzleti szférától. Legmegfoghatóbb a nonprofit kategória".

A kormányváltás eredményeként a politika a civil szervezetek szabályozási környezetének gyökeres megújulását is célul tüzte ki. 2011. év végén jelent meg az új civil törvény (és a kapcsolódó további szabályozások ${ }^{1}$ ), mely a szokásos eljárási gyakorlathoz képest több új követelményt is megfogalmazott, mint például a civil szervezetek fogalma, új civil szervezeti forma bevezetése - a civil társaság megjelenése, a közhasznúság új követelményei, megfelelőség, könyvvezetési követelmények, kötelező átalakulás, stb.

A hétköznapi statisztikai adatok a szervezetek oldaláról közelítik meg ezt a kérdést. A KSH nonprofit szervezetekkel kapcsolatos kiadványa a magyarországi civil szervezetek viszonyairól is rövid, informatív áttekintést $\mathrm{ad}^{2}$. 2011-ben mintegy 65,5 ezer nonprofit szervezet müködött Magyarországon, egyharmaduk, 23,2 ezer alapítványi formában, 42,3 ezer társas nonprofit szervezetként. A nonprofit szervezetek döntő többsége tehát civil szervezet. Ha ezt a számot a KSH 2010-es, vállalkozásokra vonatkozó adataihoz hasonlítjuk ${ }^{3}$, így nagyjából 10 vállalkozásra jut 1 nonprofit szervezet. A civil szektorban az általános KSH adatatok igazából egy viszonylag jó képet festenek a civil szektorról, melynek részletei már igen árnyaltak. A bevételek eloszlása igen egyenlötlen, a szektor meglehetősen polarizált ${ }^{4}$. A számított foglalkoztatottak mintegy negyede jutott az egyesületekre és alapítványokra. A gazdasági kapacitás mellett a humán eröforrás ellátást szokás a szféra jelentőségével kapcsolatosan megemlíteni. Noha a nonprofit szektorban a foglalkoztatottak száma nem elenyésző, annak csupán töredéke jut a civil szervezetekre. Összességében a klasszikus civil szervezetek-

\footnotetext{
${ }^{1}$ 2011.évi CLXXV. civil törvény, 2011.évi CVXXXI.törvény, 2011.évi 350. kormányrendelet, 2013.évi V.tv).

${ }^{2} \mathrm{http}: / /$ www.ksh.hu/docs/hun/xftp/stattukor/nonprofit/nonprofit11.pdf

${ }^{3} \mathrm{http}: / /$ www.ksh.hu/docs/hun/xstadat/xstadat_eves/i_qpg005a.html

${ }^{4}$ Az 5 millió Ft alatti bevétellel rendelkezők aránya 80,9\%, az 50 millió Ft feletti bevétellel rendelkező 4,3\%-nyi szervezet a szféra bevételeinek 83,8\%-val rendelkezik. http://www.ksh.hu/docs/hun/xstadat/xstadat_eves/i_qpg006.html
} 
nél nagyjából 52000 fő fóállású foglalkoztatottnak megfelelő humán kapacitásról beszélhetünk (foglalkoztatott és önkéntes együtt), ami az alig több, mint 57 000 szervezetet tekintve nem igazán jelentős, szervezetenként tehát alig éri el az egy foót a munkakapacitás és ebben benne van az önkéntes munka nagysága is. A leegyszerüsítés lehet túlzó, ugyanakkor a szektor polarizáltságát tekintve a kép még ennél is árnyaltabb lehet. Korábbi vizsgálatok is megerősítették a szektor megosztottságát (Murányi-Szerepi, 2005: 54).

Amennyiben arra gondolunk, hogy a nagyjából 60 ezer civil szervezet jelentősége mekkora, (rendelkezésre álló adataink alapján) ki kellene merüljön abban, hogy hányan vannak, mennyi a bevétele-kiadása, gazdasági kapacitása és menynyi tag, önkéntes dolgozik a szervezeti célok megvalósítása érdekében. Csakhogy a civil szervezetek javarésze nem pusztán a szervezeti tagok érdekeit kívánja támogatni, hanem az oly sokszor említett társadalmi felelősségvállalás aktív szereplői is, tevékenységük révén tisztább a környezetünk, többen és jobban tanulhatunk, egészségesebben élhetünk vagy épp jobb nemzetközi kapcsolatokra tehetünk szert. Tehát a valójában konkrétan leírható szervezetek egy nagyobb társadalmi bázis érdekei végett müködnek, a társadalom, az ország életkörülményeinek, létfeltételeinek javításán dolgoznak. Nehéz találni olyan konkrét becslést arra vonatkozóan, hogy valójában mekkora az a társadalmi bázis, melyet tevékenységük érint és arra sem, hogy az milyen területeken jelentkezik. A civil szervezetek életben maradása, és jövője attól is függ, képesek-e az ügyfelek által elvárt szolgáltatást magas színvonalon, kiváló minőségben teljesíteni (Oláh, 2008).

\section{„Civic engagement”}

A nemzetközi irodalmakban (pl. Brint-Levy 1999: 164), Cnaan-Milofsky 2007: 75) tárgyalják a „,civic engagament ${ }^{5,}$ kérdéskörét, ez alapvetően a civil mozgalmakhoz, szervezetekhez kötődő állampolgári aktivitással kapcsolatos. A „,civic engagement" azt jelenti, hogy az állampolgárok együtt dolgoznak egy közös jóért és a társadalmi tőke egy viszonos alapú kikényszeríthető bizalom mintáin nyugvó kapcsolatrendszer, mely lehetővé teszi az emberek és intézmények olyan erőforrásokhoz jutnak, mint szociális szolgáltatások, önkéntesek és támogatások. A civil az állampolgári tevékenységekkel kapcsolatos fogalom, az részvétel pedig aktív közremüködést jelent. A civil részvétel arra vonatkozik, hogy az állampolgárok civil társadalmi intézményekben, pl. nonprofit szervezetekben vesznek részt azért, hogy általános társadalmi célokat szolgáljanak. A részvétel a

\footnotetext{
${ }^{5}$ Civil részvételként használom a kifejezést.
} 
társadalom alapú szervezetekben olyan mechanizmus, mely a közjót szolgálja (Cnaan-Milofsky 2007:75). Annak ellenére, hogy igen megnőtt a rendszerváltás óta a civil szervezetek száma, a tényleges részvételi arány az EU átlaghoz képest alacsony. Cartwright et al. (2008: 3) szerint itthon csak a népesség 21\%-a tagja valamiféle szervezetnek. Az önkéntes munkában való részvételt tekintve- egy 2006-os felmérés alapján ${ }^{6}$ az állampolgárok mindössze $17 \%$-a vesz részt, vagy csinált önkéntes munkát (mi az EU átlag végén vagyunk). Legjellemzőbb a sport vagy szabadidős tevékenységekben való részvétel. A munka azt sugallja, hogy a részvétel itt alapvetően foglalkoztatottakat és önkénteseket jelent. A részvétel indikátoraként említik még az adományok felajánlását (pl. véradás is), más érdekében történő kockázatos helyzetekbe történő beavatkozást, a családokkal, barátokkal történő kapcsolattartás rendszerességét. Úgy tünik, hogy a végzettségek, státuszok szintjének csökkenésével a civil részvétel is csökken (legmagasabb menedzserek között). Bácsné (2012) vezetőkkel végzett idővizsgálatai is alátámasztják e réteg érzékenységét a társadalmi tőke környezeti változásokban betöltött szerepével összefüggésben). A civil részvétel körébe tehát számos indikátor beletartozik (önkéntesek, foglalkoztatottak, kapcsolatok, stb.) de vannak bizonyos, eddig részleteiben nem teljesen lefedett további kérdések is.

Érdekes lenne feltenni a kérdést, hogy vajon legalább ennyire fontos az is, hogy mennyi jut el belőle az ország számára? Mit jelent a társadalomnak, a gazdaságnak és elsősorban az egyéneknek a civil szervezeti szféra? A civil szervezetek ugyanis nem feltétlenül és nem mindig a tagok, az önkéntesek, a foglalkoztatottak érdekeit szolgálják, hanem egy további, mögöttes informális közösség által explicit vagy implicit módon megfogalmazott célokat is. Épp ezért lényeges, hogy mennyit és mit tud róluk környezetük, és vajon a környezet maga is felismeri-e azt, hogy saját, sokszor egyénre lebontott céljaik harmonizálnak a civil szervezetek által megfogalmazottakkal vagy épp nem.

\section{Civil érintettség}

A téma továbbvisz minket egy általam definiált olyan területre, melyet egy korábbi kutatás tanulmányozása során adaptáltam. Kovách $(2005: 25)^{7}$ a mezőgazdaság rendszerváltás utáni jelentőségét vizsgálva úgy vélte, hogy noha a foglal-

\footnotetext{
${ }^{6} \mathrm{http}: / /$ ec.europa.eu/public_opinion/archives/ebs/ebs_273_en.pdf

${ }^{7}$ A kutatás részleteiről még: Kovách I. (2012): A vidék az ezredfordulón. A jelenkori magyar vidéki társadalom szerkezeti és hatalmi változásai. Arumentum Kiadó-MTA Társadalomtudományi Kutatóközpont (Szociológiai Intézet), Budapest.42-46.old.al.
} 
koztatottak száma viszonylag alacsony szintre esett napjainkra, a társadalom többsége valamilyen módon, bár különböző mértékben mégis agrárérintett, azaz van kapcsolata a mezőgazdasággal. Kovách vizsgálatai rámutattak arra, hogy az agrárérintettség többféleképp megragadható (pl. úgy is, hogy valaki a szektorban foglalkoztatott, de úgy is, hogy termőföldje van, vagy épp mezőgazdasági iskolázottsága van, vagy piaci vagy akár saját értékesítésre állítanak elő mezőgazdasági terméket. A különböző érintettségi kategóriák vizsgálata révén a mezőgazdaság helyzete nem jelentéktelen: „2005-ben így a felnőtt lakosság 51,6 százaléka volt közvetlenül agrárérintett"

A civil szervezeteket tekintve világos, hogy például egy településen müködő civil szervezet, néhány 10 fő taggal, önkéntessel vagy jobb esetben foglalkoztatottal és bizonyos bevétellel-kiadással jelentőségében nem csupán ennyit jelent, nem egyszerüsíthető le ennyire jelentőségük, illetve az általuk kifejtett hatás ebben nem merül ki. Müködtethetnek teleházat, biztosíthatnak ingyenes szolgáltatásokat, rendezhetnek falunapokat vagy épp nyírhatnak parlagfüvet vagy utcát, járdát takaríthatnak, melyek nem elsősorban externáliák, ugyanis a szervezetek céljai épp ezzel vannak összefüggésben, erre irányulnak. Az utóbbi 10 év jelensége a civil szervezetek és az állami hivatalok összefogása, amellyel a munkaerőpiacon hátrányt szenvedőket támogatják. A segítség ilyen formája az európai országokban hosszú évek jellemző civil feladat, amely a 2000-es évek eleje óta különböző pályázatok útján vált hazánkban lehetővé (Móré 2012). A civil érintettség, az előbb említett vizsgálathoz hasonlóan, hüebb, valósabb képet adhat a civil szervezetek hatásáról, vagy épp kiegészíti, újraformálja gondolkodásunkat a civil szervezetek müködésével kapcsolatosan.

A fogalom maga összetett, és több oldala van. A civil érintettség általánosságban azt jelenti, hogy milyen összefüggés jellemzi a civil szervezeti szférát és az embereket - milyen a civil szervezetek hatása az emberekre. Részleteiben azt jelenti, hogy a civil szféra a társadalom elemi egységeinek életét tekintve mit jelent a civil szervezet, milyen a civil szervezetekkel kapcsolatos társadalmi intenzitás, milyen összefüggés van a civil szervezetek és a társadalom, az élet javítása között, milyen az érintettség mélysége, milyen területeken érintett, milyen erősségü a civil szervezetek hatása. Az említett változók egy összetett fogalom különböző aspektusait veszik górcső alá, és így a sokszor különböző helyről származó információk és különböző megközelítések mellett néhány adattal jellemzi a civil szervezetek és a társadalom viszonyát. Az egyik ilyen változó, az emberek munkával kapcsolatos viszonyainak és a megélhetésének, anyagi boldogulásának kérdése például nem jelenik meg határozottan a KSH nomenklatúrában. Ibrahim-Hulme (2010:2) szerint egyre jelentősebb a figyelem a szegénység és nyomor csökkentése irányában, és felmerül a kérdés, hogy a civilek miért feministák vagy épp környezetvédők, és miért nem szegénységcsökkentők?A civileknek ugyanis kulcszerepe kellene lennie az ilyen ügyek pártolásában, az 
ilyen ügyekben való részvételben és a fenntartható szegénységcsökkentés elősegítésében.

Maga az érintettség alapvetően két oldalról is megközelíthető. Elsőként a hétköznapi embereknek, a lakosoknak van álláspontjuk, véleményük, így attitüdjük megismerhető a civil szervezetekkel kapcsolatosan. Egy nagymintás reprezentatív felmérés ennek részleteiről többet elárulhatna.

Létezik emellett vonatkozó véleménye maguknak a civil szervezeteknek is, látják, megbecsülhetik, tapasztalhatják, hogy milyen területekre terjed ki müködésük ${ }^{8}$, hány emberre vonatkozóan, milyen mélységben.

A cikk lehetőséget ad arra, hogy egy nem régi kutatás eredményeit a fentiekkel kapcsolatosan bemutathassam. A kutatások lényegi része egy választott településen a civil érintettség részleteinek bemutatása. A település választásának indokai között szerepel annak nagysága, periférikus elhelyezkedése, a mintavétel korlátai, valamint a civil szervezetek csekély száma is.

A vizsgált település a Sárréti Kistérség egyik legkisebb települése. HajdúBihar megyében, meglátásom szerint igen periférikus területen fekszik, viszonylag távol még a kisebb városoktól is. A település legnagyobb lélekszámát az 1800-as évek közepén regisztrálták ( 800 fö) ez azóta sajnos folyamatosan csökken, a lakosság lélekszáma a statisztika szerint jelenleg alig több, mint 202 fö (informális információk szerint 200 alatt van). A települést végigjárva az igazi falusi jellegủ kistelepülés. Egy ilyen kistelepülésen szinte mindenki ismeri egymást, az emberi viszonyok meghittebbek, közvetlenebbek. Utasi (2012: 8) szerint a lokális közösségi identitás fontos kritériuma és mérőszáma a falu közösségéhez tartozás érzése, a kötődés, és a civil szervezetek ezeknek a közösségszerveződéseknek a színterei. A településen ugyanakkor mindössze 2 civil szervezet müködik, egy egyesület és egy alapítvány, ahol a tagok és önkéntesek száma a kettő esetében is jó, ha a 15 föt eléri. Valójában a periferikus elhelyezkedés, a kormegoszlás miatt feltételezhető, hogy a civil szervezetekkel kapcsolatos véleményt ezzel a két szervezettel kapcsolatosan szükítik le a válaszadók. Ritka, és igencsak alkalmi jellegü, ha más településen müködő civil szervezetek munkájába egy-két helyi bekapcsolódik.

A vizsgálat módszere tekintetében a reprezentativitást biztosító K-szempontú szisztematikus mintavétellel dolgoztunk ${ }^{9}$. A vizsgálat időpontjában rendelkezés-

\footnotetext{
${ }^{8}$ Az alapító okiratban vagy alapszabályban megfogalmazottakkal ellentétben-hasonlóan a vállalkozásokhoz-nem mindegyik megfogalmazott tevékenységgel foglalkoznak, egy jelentős részük inkább csupán néhány területen aktív.

${ }^{9}$ A kutatás során egy kutatással két párhuzamos vizsgálatot végeztünk: jómagam általános érintettségi, Pierog Anita kolléganőm pedig gazdasági érintettséggel kapcsolatosan gyüjtött adatokat. A kutatás a Balassi Ferenc Kulturális és Közösségteremtő Egyesület
} 
re állt a helyi lakossági lista, mely során a 202-fős lakosság nagyjából felét, 100 föt sikerült lekérdezni a civil érintettség kérdéskörével kapcsolatosan. A felmérést felkészített kérdezőbiztosokkal végeztettük el, a megbízhatóságot külön adatok bekérésével garantáltuk. A teljes sokaságon belül a megbízhatósági intervalluma 95\%-os valószínüségi szinten +/- 6.98. A mintavétel véletlen, és az említett megbízhatóság mellett viszonylag pontos becslést tesz lehetővé, az egész településre vonatkozóan. A teljes vizsgálati eredményekből csupán néhány részletet ragadnék ki.

A kérdőíves felmérés mintájának interjúazonosítóit tekintve elmondható, hogy közel azonos arányban voltak férfi és nő válaszadóim, megkérdezettek 53\%-a férfi, 47\%-a nő. Kormegoszlását tekintve a minta többségében föleg középkorú illetve annál idősebb, a 60 év felettiek aránya egy harmad, az 50 felettieket tekintve arányuk majd 50\%, tehát úgy gondolom, hogy korfát tekintve idősödő településről van szó. Az iskolai végzettségét tekintve a helyzet nem minősíthető előnyösnek, a felsőfokú végzettségüek aránya igen alacsony (3\%), a maximum 8 általánossal és annál alacsonyabb végzettségüek aránya több, mint $50 \%$, illetve közel 40\% a középfokú végzettségüek aránya. A megkérdezettek 34\%-a foglalkoztatott, a munkanélküliek aránya 14\%, az aktívak aránya összességében tehát $48 \%$, ez a megyei és az országos adatoknál valamelyest rosszabb. Az inaktívak aránya 16\%, a nem munkaképes korúak aránya $36 \%$.

A survey első szakmai kérdése arra vonatkozott, hogy milyen a megkérdezettek alapvető ismerete a civil szervezetekkel kapcsolatosan. Az eredményeim alapján úgy tünik, hogy a megkérdezettek csupán harmada tudja hogy mit is jelent egy civil szervezet. A megkérdezettek közel felének $(43,4 \%)$ ismerete a civil szervezetekröl közepes, inkább homályosabb (vannak elképzeléseik). Emellett a minta további majd negyede $(23,2 \%)$ nem igazán tudja, mi is a civil szervezet. Úgy tűnik, ez az ismeret némileg végzettség függő, mivel valamennyi felsőfokú végzettségü tisztában van vele, a középfokú és alapfokú végzettségüek ismerete már összességében inkább homályos, a képesítés nélküliek többsége nem tudja, hogy mi a civil szervezet. Némileg korfüggő is, mivel a fiatalabb korosztály inkább, az idősebbeknek, föként a 60 év felettieknek nem sokat mond a civil szervezet kifejezés.

Érdekesnek tünik azt vizsgálni, hogy a civil szervezetek képe a lakosságot tekintve mennyire kapcsolódik össze valamiféle pozitívummal, azaz mennyiben függ össze a helyiek véleménye szerint a társadalom, az élet javítása a civil szervezetekkel. Az eredmények szerint a lakosság ebben a tekintetben inkább bizonytalan (1.ábra).

„Civil érintettség módszertana és civil érintettségi vizsgálatok” szakmai NEA pályázat keretében valósult meg. 


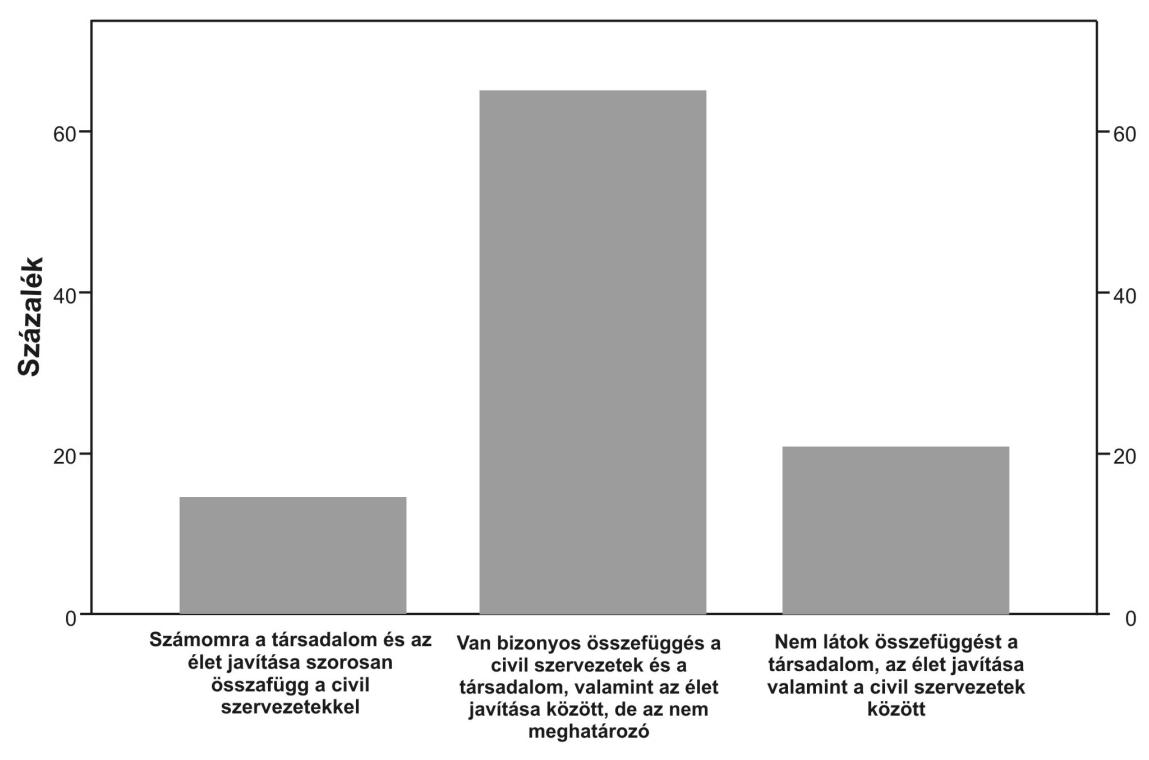

1. ábra: Az vizsgált minta megítélése a civil szervezetek pozitív hatásáról.

Forrás: Saját vizsgálatok, 2013.

A lakosság többségének véleménye arra utal, hogy a többség föként bizonytalan (64,9\%) vagy inkább elutasító azzal kapcsolatosan, hogy a civil szervezetek müködése a társadalom és az élet javítását szolgálná. A válaszadók csupán 14\% gondolta úgy, hogy a civil szervezetek számukra egyet jelentenek az élet javításával. Az eredményt úgy értékelem, hogy a helyzet ebben a tekintetben kedvezőtlen, a helyi civil szervezet hatása nem elsősorban pozitív, sőt többségében inkább bizonytalan és kisebb részben elutasító, tehát a társadalom és élet javításával kapcsolatos érintettség igen gyenge. Korosztály tekintve elsősorban a fiatalabb korosztály ítélete pozitívabb, egészen 50 éves korig, az 51-60 éves korosztály inkább elutasító, az ennél idősebbek pedig inkább bizonytalanok. A végzettségek tekintetében a középfokú végzettségüek inkább bizonytalanok, az ennél alacsonyabb végzettségüek inkább bizonytalanok és elutasítóbbak, a magasabb végzettségüek elsősorban elfogadóbbak. Az inaktívak, nem munkaképes korúak és munkanélküliek inkább bizonytalanok vagy elutasítóak, és a foglalkoztatottak elsősorban bizonytalanok.

A civil érintettség mérhetőségének tekintetében több kategória definiálható. Nyilván ez a kategórialista nem feltétlenül végleges, további szakértői munka és a tapasztalat ezt tovább bővítheti, módosíthatja. 
$>$ A foglalkoztatott és önkéntesi tevékenység erős érintettséget jelent.

$>$ Közepesen érintett az, aki például részt vesz a programjaikban vagy részesül juttatásaikban.

> Gyengén érintett az, aki föként teoretikusan foglalkozik a témával, érdekli, olvas róla, vagy épp szimpatizál, de nem tesz egyebet.

$>$ Az utolsó két kategória összevonható, nem érinti, de tudja miröl van szó vagy egyátalán nincs információja, így mindkettő alapvetően passzív az érintettség szempontjából.

A település lakosságának érintettségének részleteit a 2 . ábra mutatja be:

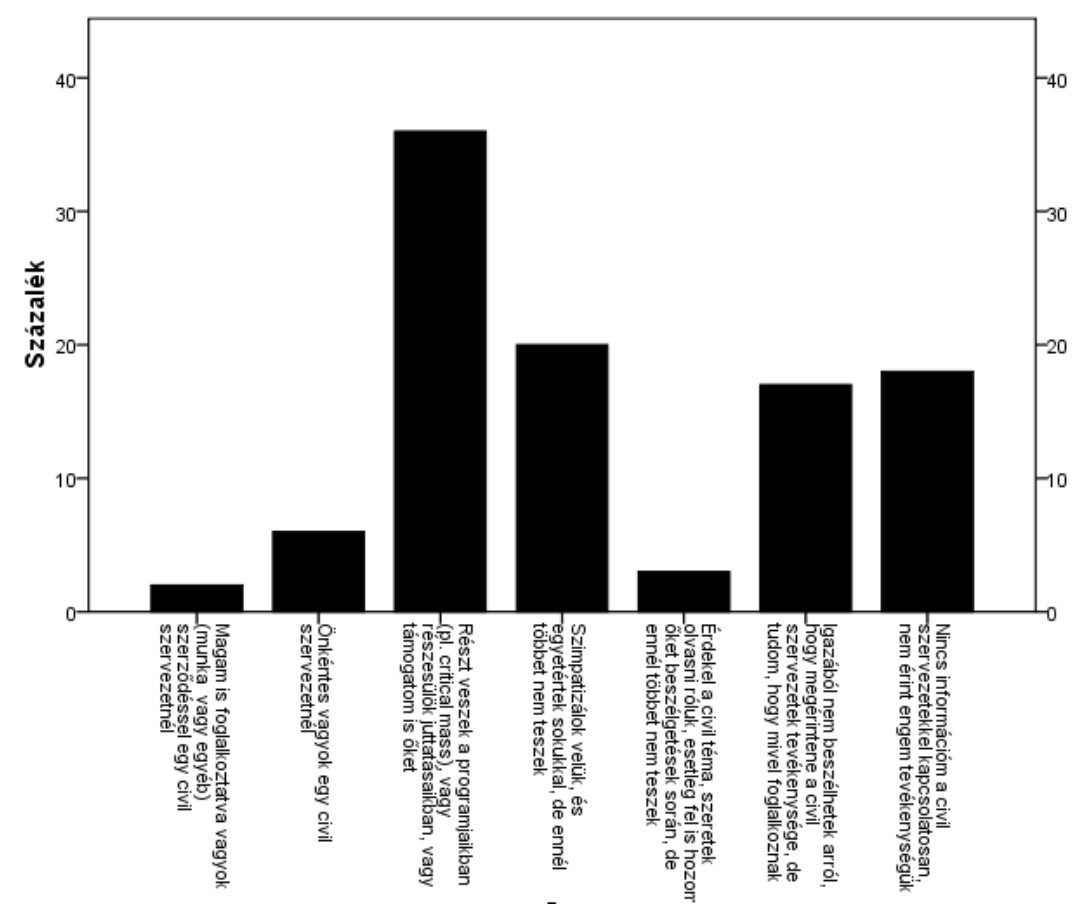

2. ábra: Az vizsgált minta civil érintettségi mélységének megoszlása.

Forrás: Saját vizsgálatok, 2013.

$\mathrm{Az}$ eredmények azt mutatják, hogy a válaszadók megoszlását tekintve $8 \%$ arányban számoltak be erős érintettségről, két válaszadó érintettsége igen erős, 6\%-ban ennél valamelyest gyengébb. A válaszadók érintettsége többségében közepes, 36\% részt vesznek programjaikban vagy részesül juttatásaikban. Egy igen jelentős arány, 20\% szimpatizál velük, és egy igen kis arány $(3 \%)$ fỏ foglalkozik velük elsősorban teoretikusan, de ennél többet ők nem tesznek. A minta 
egy jelentős részét nem érinti a civilek tevékenysége, $17 \%$ tudja, hogy mivel foglalkoznak, de nem érintettek, és $18 \%$ biztos abban, hogy nem érintett, és nincs is információja a civil szervezetek tevékenységével kapcsolatosan. Az összevont eredmények alapján azt mondhatom, hogy a civil érintettség tekintetében a teljes lakosság

$>7,8 \%$-a erösen érintett

$>35,2 \%$ közepesen érintett

$>22,5 \%$ gyengén érintett

$>34,3$ nem érintett.

Az érintettségi görbe tehát nem szimmetrikus, a település lakossága inkább közepesen vagy ennél gyengébben érintett. Az alacsony érintettség vélhetően több dologgal is összefügg, így a korral és feltehetőleg a végzettséggel sőt a foglalkoztatottsággal is.

A civil szervezetek tevékenységei-alapító okiratukban vagy alapszabályukban megfogalmazottak alapján- sokszor szerteágazóak, sokuk egyszerre több célt, és ehhez több tevékenységet is megfogalmaz. Ugyanakkor az már más kérdés, hogy a megfogalmazott célokhoz kapcsolódó tevékenységek mennyiben jutnak el az emberekhez. Ezért érdemes azt is vizsgálni, hogy a civil szervezetek tevékenysége milyen területeken érinti a település lakóit. Az eredményeket a 3. ábra mutatja be.

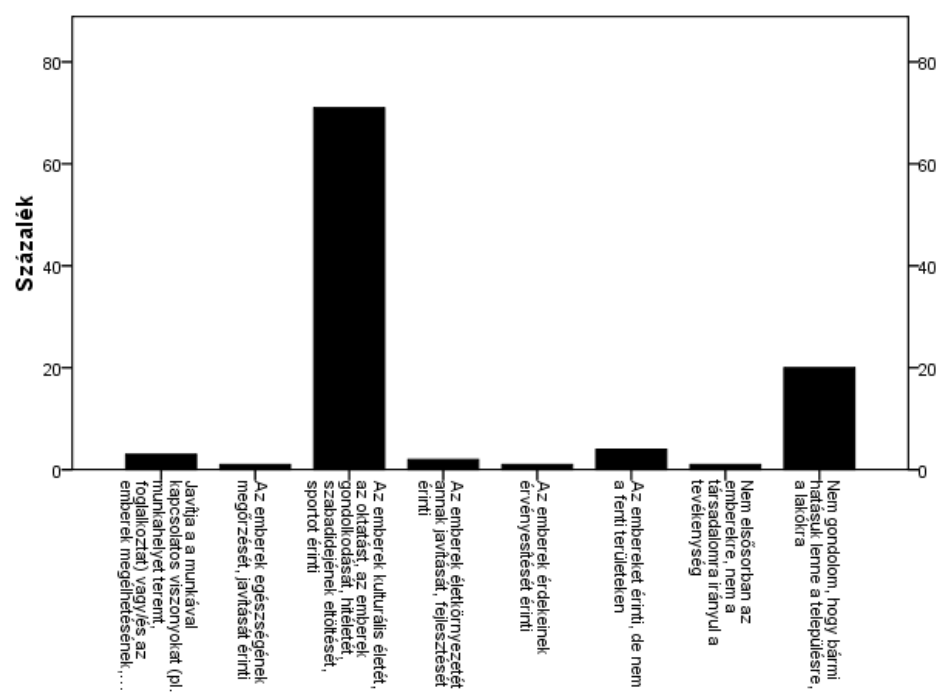

3. ábra: Az vizsgált minta véleményének megoszlása az érintettség területeiről.

Forrás: Saját vizsgálatok, 2013. 
A civil szervezetek hatása a településen az eredmények alapján elsősorban kulturális területen, oktatási területen, az emberek hitéletében, gondolkodásában, szabadidőjének eltöltésében, és a sport területén érezhető. Ez egy viszonylag magas arány, $71,4 \%$-a a megkérdezetteknek ezeket a területeket jelölte meg. A további eredmények tekintetében úgy vélhető, hogy a munkával és megélhetéssel kapcsolatos viszonyok terén a helyi civilek hatása alig érezhető $(3,1 \%)$, hasonlóképp az egészségjavítás $(1,0 \%)$, életkörnyezet javítás $(2,0 \%)$, az érdekérvényesítés $(1,0 \%)$, egyéb, az emberekkel kapcsolatos terület $(4,1 \%)$, illetve nem az emberekkel kapcsolatos területekhez (1,0\%). A megkérdezettek 20,4\%-a úgy gondolta, hogy a civil szervezetnek nincs hatása a településre, a lakókra. Összességében tehát az érintettség fókusza kulturális, hitéleti, oktatási, gondolkodási, szabadidő eltöltési, sport területeken jelentkezik, majd háromnegyed arányban, ezen kívül ugyanakkor a civil szervezete hatása alig érezhető, sőt a megkérdezettek egy ötöde szerint nincs is hatása a településre és a lakókra. Úgy tünik a civilek hatóspektruma tehát nem széles, és csupán néhány területre koncentrált.

A vizsgálat utolsó kérdése azt mérte, hogy milyen a civil szervezetek hatásának erőssége. Az eredmények arra utalnak, hogy a civil szervezetek helyi hatása inkább közepes, vagy attól gyengébb (4.ábra)

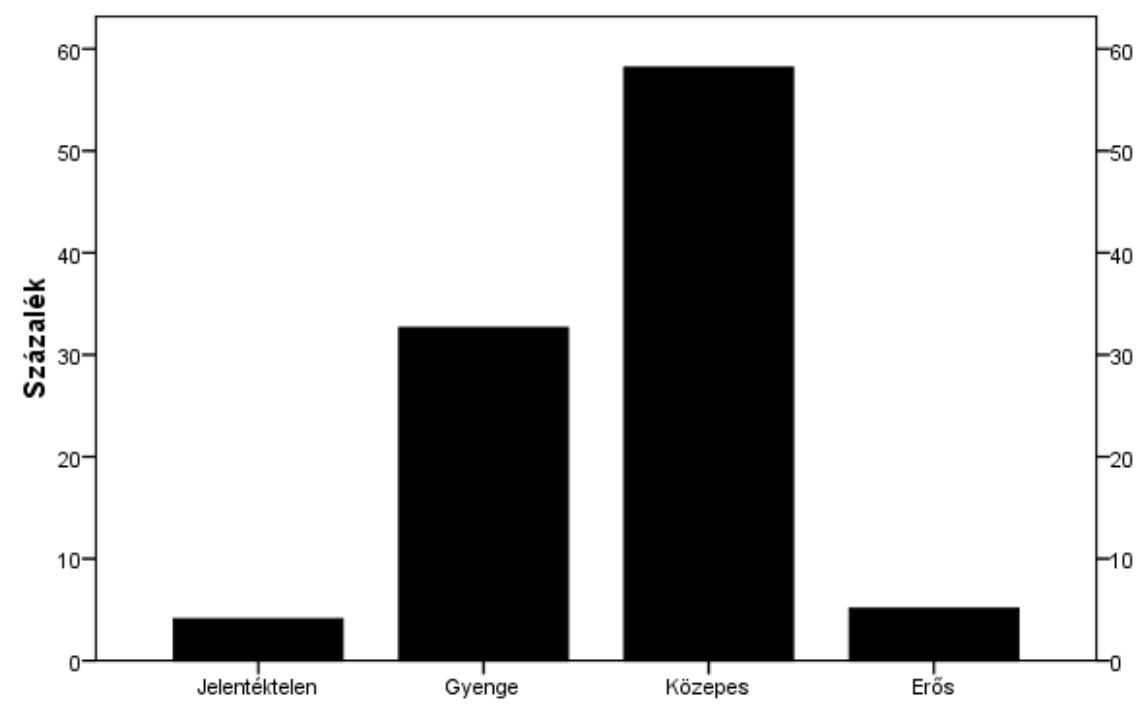

4. ábra: Az vizsgált minta véleménye a civil szervezetek hatásának erősségéről. Forrás: Saját vizsgálatok, 2013. 
A megkérdezettek az ötfokú skálán négy választ jelöltek meg csupán, ezekböl az látható, hogy a válaszadók mindössze $5 \%$-a szerint erös a civil szervezetek hatása, $4 \%$ véleménye szerint ezzel épp ellenkező, azaz jelentéktelen, 32,7\% szerint hatásuk gyenge, és $58,2 \%$ szerint a civil szervezetek hatása közepes a településre vonatkozóan. Főként a fiatalok szerint erősebb a hatás, egyéb összefüggés ebben a tekintetben nem mutatható ki. A hatás erősségét elsősorban a középfokú végzettségüek jelezték, más összefüggés ebben a tekintetben sem volt kimutatható. A munkanélküliek tekintetében a hatás inkább gyengébb, hasonlóan a foglalkoztatottakhoz és a nem munkaképes korúakhoz, az inaktívak tekintetében ez inkább közepes erősségü. Az érintettségi görbe úgy tűnik, hogy erősen balra tolódott, így a civil szervezetek hatása a helyiek szerint inkább közepes, vagy annál gyengébb.

\section{Következtetések}

A civil szervezetek szerepének, jelentőségének, hatásának mérése alapvetően egy komplex tevékenység, és ahhoz, hogy valós képet kapjunk, egyrészt az adatok részleteit is ismerni kell, másrészt többféle adatforrásra is érdemes támaszkodni. Különösen konkrétumok alkalmával lehetnek problémák, ha a KSH-t tekintjük javarészt több mint 2 éves adatokkal lehet találkozni, és a részletek ilyenkor is legtöbbször az önkéntesek és tagok számában merülnek ki. Az érintettség újabb változókat is bevezet, és jobb becslést adhat - érvényessége miatt egy vizsgált populáció viszonyairól.

A saját eredmények kapcsán -a vizsgált település tekintetében- arra lehet következtetni, hogy a civil szervezetek hatása helyileg nem igazán erős. A vizsgált településen a lakosság többsége vél valamiféle összefüggést felfedezni a civil szervezetek és társadalom, az élet javítása között, de ez nem igazán meghatározó. A lakosok többsége inkább közepesen vagy gyengén érintett, közel egyharmaduk semmiféle formában nem érintett. A civil szervezetek hatása a helyiek szerint inkább közepes, vagy annál gyengébb. Helyi szinten a civil szervezetek jelenlegi vizsgálataim, területeim és módszereim tekintetében - nem elég erősek jelenleg a neki tulajdonított feladatok ellátásban és társadalomra kifejtendő hatásukban. Különösen érvényes ez olyan területen, mint például a munkahelyteremtés vagy bővítés, mely helyileg igen fontos lenne. Érdekes lehetne megtudni, hogy vajon mit is várnak a helyiek a két müködő civil szervezettől, vajon mivel tudnának a helyiek maguk is hozzájárulni a szervezetekhez, afféle települési erőforrás és szakértelem leltár tekintetében vélhetően további párhuzamokat lehetne kiépíteni a szervezetek és a helyi lakosság között. 


\section{Irodalomjegyzék}

1. Bácsné Bába É. (2012): Változásmenedzsmenthez kapcsolódó reakció idő vizsgálatok. In: Virtuális Intézet Közép-Európa kutatására Közleményei IV. évf. 2. szám (No.8.) A-sorozat 1. Gazdálkodás- és szervezéstudományi tematikus szám 2012. Szeged, pp. 66-74.

2. Brint, S., Levy, C.S. (1999). "Professions and Civic Engagement: Trends in Rhetoric and Practice, 1875-1995." In: Skocpol, T. - Fiorina, M.P. (ed.): Civic Engagement in American Democracy. Brookings Institution Press; Russell Sage Foundation. Washington, D.C.; New York.

3. Cartwrigh, A., Sik E., Svensson S. (2008): The Impact of Civic Engagement on The Quality of Life in Hungary. Social Capital Working Papers 2008/3.Central European University, Budapest.

4. Cnaan, R.A., Milofsky, C. (ed.)(2007): Handbook of Community Movements and Local Organizations (Handbooks of Sociology and Social Research). Springer.

5. Ibrahim, S., Hulme, D. (2010): Has civil society helped the poor?-A review of the roles and contributions of civil society to poverty reduction. BWPI Working Paper 114. University of Manchester Brooks World Poverty Institute. http://www.bwpi.manchester.ac.uk/resources/Working-Papers/bwpiwp-11410.pdf (2012.12.25)

6. Móré M. (2012): Hátrányos helyzetűek és romák munkaerőpiaci visszailleszkedésének segítése tanácsadási módszerekkel. In: Gortka Rákó E. (szerk): Társadalomtudományi Tanulmányok V. DUPress Kiadó Debrecen pp. 69-77.

7. Murányi I., Szerepi A. (2005): Civil esélyek Hajdú-Bihar megyében. Hajdúsági Hallgatói Önkormányzatok Kulturális Egyesülete,Debrecen. 54 p.

8. Oláh J. (2008): A szociális gazdaság jellemzői Magyarországon. „Hagyományok és új kihívások a menedzsmentben: 140 éves a vezetés és szervezés oktatása a debreceni gazdasági felsőoktatásban" c, nemzetközi konferencia. Szerk.: Dienesné Kovács E.- Pakurár M. Debreceni Egyetem, Debrecen, 2008. október 2-3. 450-456.p. ISBN: 978-963-9822-08-5.

9. Utasi Á. (2012): Közösségi és közéleti aktivitás. Vizsgálat három ország hét magyar kistelepülésén. MTA TK Politikatudományi Intézet, Budapest.

Szabados György: egyetemi adjunktus

Debreceni Egyetem, Vezetés és Szervezéstudományi Intézet, Vezetéstudományi Tanszék

4028 Debrecen, Böszörményi út 138. 
